\title{
Twenty years of histochemistry in the third millennium, browsing the scientific literature
}

\author{
Carlo Pellicciari
}

Department of Biology and Biotechnology, University of Pavia, Italy

\begin{abstract}
Over the last twenty years, about 240,000 articles where histochemical techniques were used have been published in indexed journals, and their yearly number has progressively increased. The histochemical approach was selected by researchers with very different scientific interests, as the journals in which these articles were published fall within 140 subject categories. The relative proportion of articles in some of these journal categories did change over the years, and browsing the table of contents of the European Journal of Histochemistry, as an example of a strictly histochemical journal, it appeared that in recent years histochemical techniques were preferentially used to mechanistically investigate natural or experimentally induced dynamic processes, with reduced attention to purely descriptive works. It may be foreseen that, in the future, histochemistry will be increasingly focused on studying the molecular pathways responsible for cell differentiation, the maintenance or loss of the differentiated state, and tissue regeneration.
\end{abstract}

Key words: Histochemistry; scientific literature.

Correspondence: Carlo Pellicciari, Dipartimento di Biologia e Biotecnologie "Lazzaro Spallanzani”, Università degli Studi di Pavia, Via A. Ferrata 9, 27100 Pavia, Italy.

E-mail: carlo.pellicciari@unipv.it 


\section{Introduction}

At the beginning of the year 2000, Raymond Coleman published in Acta Histochemica two interesting commentaries on the role and fate of histochemistry in the new millennium. ${ }^{1,2} \mathrm{He}$ complained that non-histochemists often perceive histochemistry "as an archaic term primarily associated with stains and staining techniques" so that its right nature and importance are made unclear. Then, he proposed to "adopt a new and creative terminology to describe" the discipline in order "to popularize the viewpoint that histochemistry and cytochemistry remain at the forefront of modern cell biology". To do this, he even hypothesized that the names of histochemical Societies and histochemical Journals had to be changed, to make them more modern and attractive. Twenty years later, we realize that such a "creative semantic change" (in Coleman's words) did not extensively occurred, and perhaps the scientists' attitude toward histochemistry is not so different from the one in 2000 .

\section{Articles published in 2000-2020, where histochem- istry was used}

Browsing the Web of Science database for the articles of the last twenty years where the words "histochemistry", "immunohistochemistry", "in situ hybridization", "lectin histochemistry" or "enzyme histochemistry" appear in the title, abstract or author keywords, we observe that about 240,000 papers have been published in indexed journals: their number has progressively increased from about 9300 in 2000 to 15,000 in 2019 (14,000 to date, in 2020) (Figure 1A). This confirms that during these years, histochemistry has even increased its impact on the scientific literature, especially in the biological and medical fields. ${ }^{3}$

The journals in which these articles were published cover more that 140 subject categories, thus strengthening that the histochemical approach is (sometimes unconsciously) chosen by researchers with largely different scientific interests. Most of the "histochemically classified" articles were published on journals belonging to

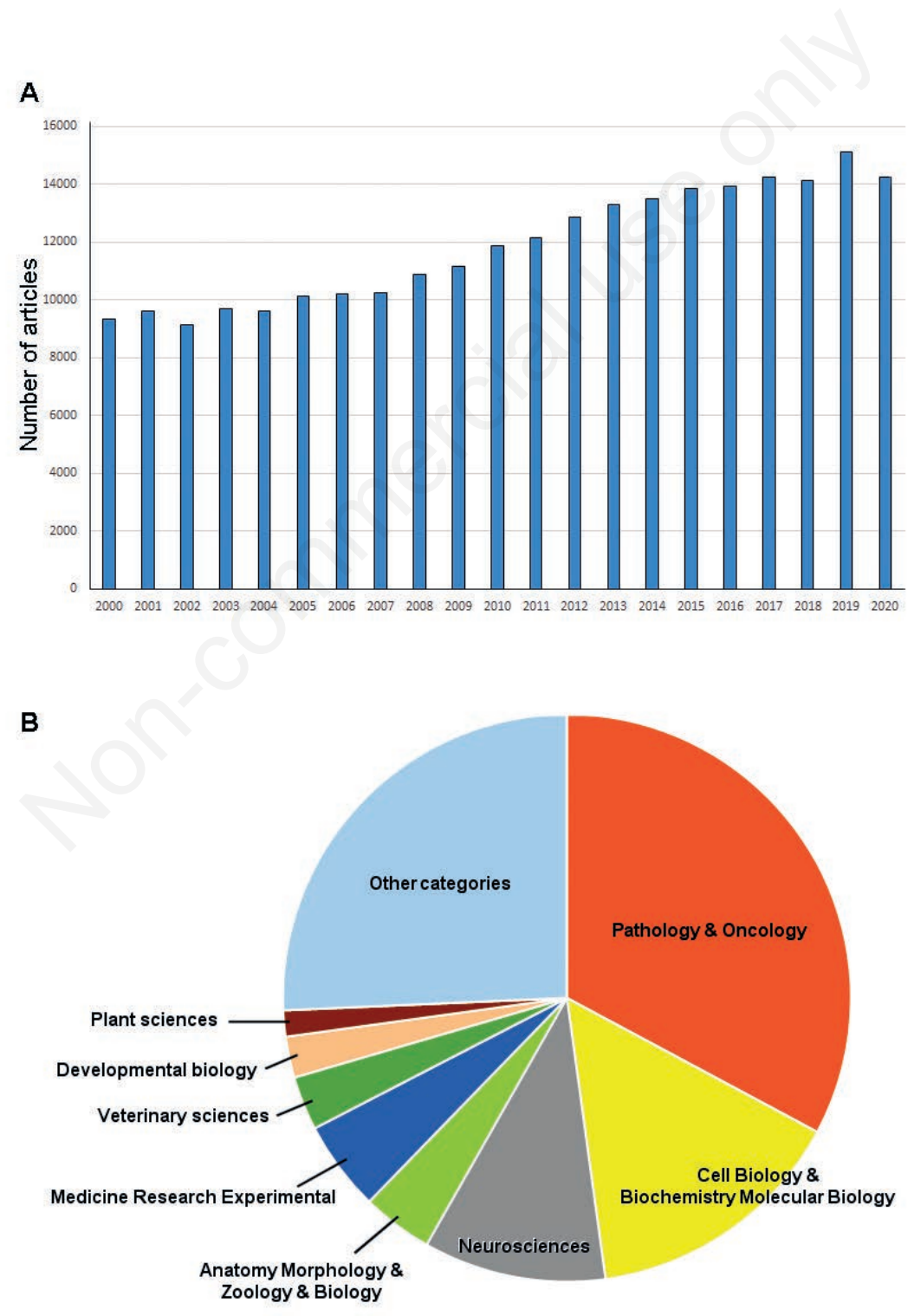

Figure 1. A) Number of articles where histochemical techniques were used, and which have been published in indexed journals in the time interval 2000-2020. B) Percentage of the articles that appeared in indexed journals of different categories during 2000-2020 (source: the Web of Science database). 
life sciences: in fact, about $75 \%$ of the papers appeared in the journals' categories Pathology \& Oncology (34\%), Cell Biology \& Biochemistry Molecular Biology (15\%), Neurosciences (10\%), Medicine Research Experimental (5\%), Anatomy Morphology \& Zoology \& Biology (4\%), Veterinary Sciences (3\%), Developmental Biology (2.5\%) and Plant Sciences (1.5\%) (Figure 1B). It is interesting to observe that the relative proportion of articles in some of these journal categories did change over the years (Figure 2). The percentage of articles in Pathology \& Oncology was around $25 \%$ in 2000 but increased to $40 \%$ in 2016 (about $36 \%$ in 2020): this was especially due to the progressively larger number of articles published in journals of Oncology (whose percentage doubled in 2020 , from the $12 \%$ in 2000). The use of histochemical techniques also increased in the journals of the category Medicine Research Experimental (from 3\% to 9\% of the published articles). On the contrary, the percentage of articles in the category Neurosciences decreased from $17 \%$ to $6 \%$; this negative trend also occurred for the articles in Cell Biology \& Biochemistry Molecular Biology (from 18\% to 14\%) and those in Developmental Biology (from about $4 \%$ in 2000 to $1 \%$ in 2020). Minor fluctuations were only observed for the categories Morphology \& Zoology \& Biology, Veterinary Sciences, and Plant Sciences

Considering the subject categories, it is obvious that the great majority of the papers in which histochemistry was used have not been published in strictly histochemical journals; in these latter ones, the authors' interests and articles' subjects may have progressively been changing as well, during these last twenty years.

\section{How the articles' subjects changed in a histochem- ical journal}

To test this hypothesis, I browsed the tables of contents of the European Journal of Histochemistry, as an example of a longestablished histochemical journal that has traditionally been open to a wide assortment of subjects, from cytology and histology in animals and plants, to human and veterinary medicine, to developmental biology.

A total of 880 scientific articles have been published from January 2000 to date. Due to the relatively small number of papers, they have been divided into three groups (the first one from 2000 to 2008 , the second one from 2009 to 2017, and the third one from 2018 up to now), and the articles have been assigned to the following topics: Methods, Tumor and non-tumor diseases, Cell biology, Neurosciences, Animal biology (including Zoology, Microanatomy and Normal Histology), Experimental research and medicine, Veterinary sciences, Developmental biology and Plant Sciences (Figure 3).

The articles dealing with new methods or technical refinements were numerous and their percentage increased mainly in the last three years ${ }^{4-19}$ when improvements in all the different steps of

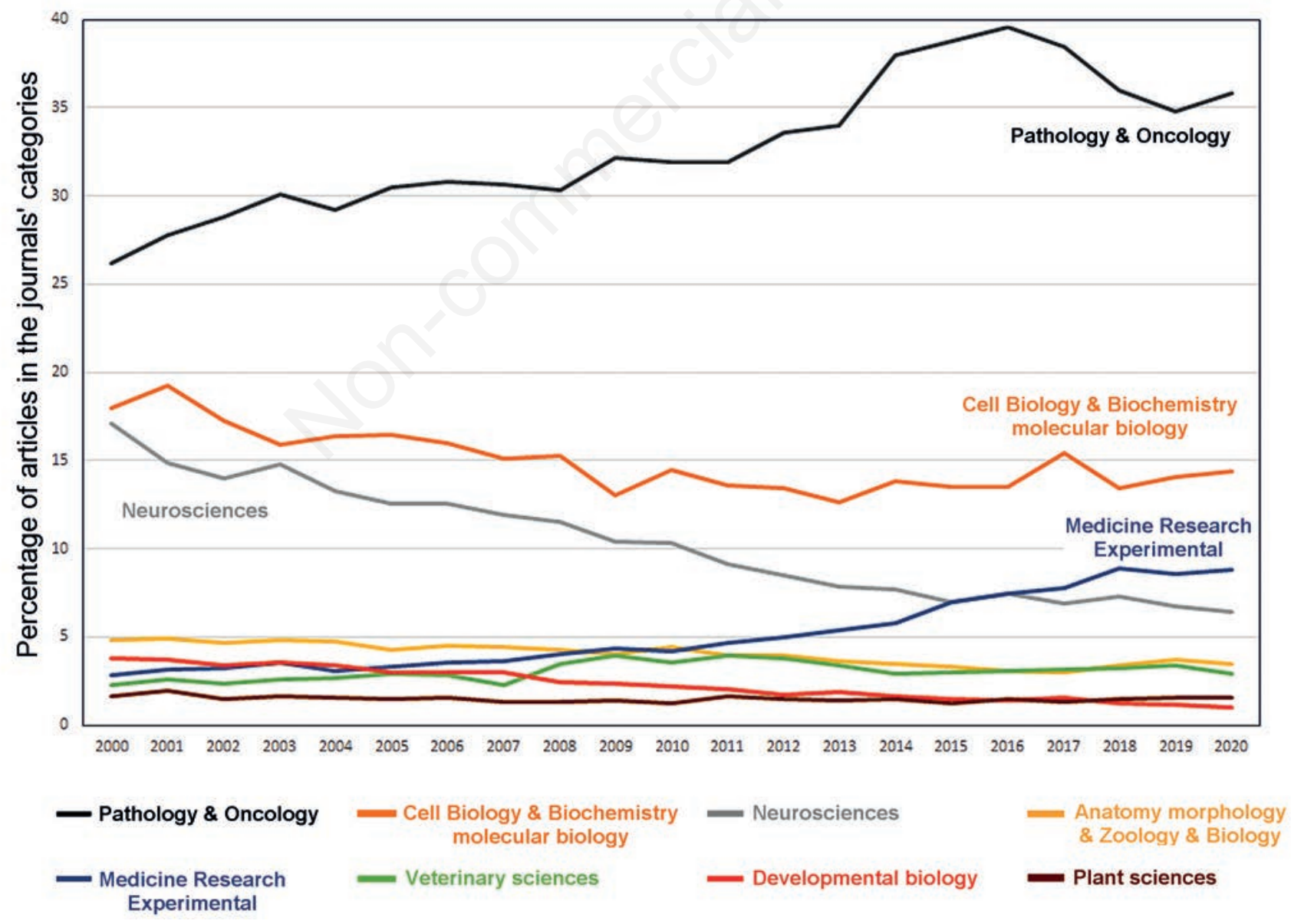

Figure 2. Percentage of articles published yearly in journals of the different categories considered in Figure 1B. 
tissue preparation were proposed, from fixation ${ }^{4-8}$ and embedding, ${ }^{9}$ to antigen retrieval ${ }^{10-11}$ and staining. ${ }^{12-15}$ Several papers dealt with ultrastructural cytochemistry, ${ }^{9,15,16}$ imaging techniques ${ }^{17-19}$ and microanalysis. ${ }^{20}$ This is not surprising for a histochemical journal, as setting up refined techniques is crucial for their appropriate and targeted application to visualize specific chemical species under different detecting procedures.

In recent years, there was no significant change in the percentage of articles published in Neurosciences ${ }^{21-29}$ and Veterinary sciences, ${ }^{30-31}$ whereas the one of those on Animal biology ${ }^{33-43}$ decreased.

No doubt, the scientific field where histochemistry has been (and still is) most largely used is histopathology; this was observed in the present survey of the whole scientific production of the last twenty years (Figure 1B), and it is confirmed by the fraction of articles on tumors ${ }^{44-58}$ and non-tumor diseases ${ }^{59-69}$ recently published in our journal. It is worth noting that in 20002009 more than $90 \%$ of the articles on tumors were aimed at describing disease-specific markers suitable for diagnosis or prognosis, whereas in a few papers only attempts were made to study the molecular mechanisms responsible for tumor onset and progress; these latter processes were, on the contrary, investigated in more than $35 \%$ of the articles published in the last three years. Histochemistry was used in parallel with molecular techniques as the proper approach to mechanistically explain the molecular basis of different diseases; this special attention to the cellular mechanisms responsible for pathological processes may also explain the progressive decrease of the published articles on basic Cell biology. Consistently with the trend observed in Figure 2, the papers on Experimental research and medicine have become more numerous: investigations were performed on animals in vivo ${ }^{70-81}$ or on cultured cells, ${ }^{82-89}$ as experimental systems for human pathologies, to elucidate the effects of the administration of physical or pharmacological agents. The papers on Developmental biology also increased: besides those on embryological development, ${ }^{90-96}$ several ones were focussed on stem cells ${ }^{97-101}$ and tissue regeneration. ${ }^{102-106}$ The application of histo- chemistry in the field of Plant sciences seems to have revived especially in the last year. ${ }^{107-110}$

As a general observation, we realize that histochemical techniques were preferentially used to investigate natural or experimentally induced dynamic processes at the molecular level, with reduced application in purely descriptive works.

\section{Concluding remark}

The long history of histochemistry started in 1829 with the seminal work Essai de Chimie Microscopique Appliquée à la Physiologie (ou l'art de transporter le laboratoire sur le porteobjet dans l'étude des corps organisés) by Francois-Vincent Raspail; ${ }^{111}$ since then, histochemistry developed and evolved in parallel with the growth and progress of life sciences. The reason for the extensive use of histochemistry by researchers in a variety of scientific fields is certainly due to the unique opportunity this discipline offers to specifically locate molecules in the tissues, cells and subcellular sites where they are present and exert their structural and functional roles. Thanks to ultrastructural cytochemistry $^{16}$ and the tremendous improvement in super-resolution microscopy, ${ }^{112,113}$ it has become possible to track histochemically labelled molecules at the nanoscale by microscopy imaging, and this has often been crucial to reach a mechanistic explanation of the cell functions in organs and tissues, under physiological or pathological conditions.

It is easy to foresee that, in the years to come, histochemistry will be even more oriented toward the understanding of the biocomplexity by elucidating the molecular pathways responsible for cell differentiation, the maintenance or loss of the differentiate state, and tissue regeneration. These topics will likely be the subjects of the large part of the manuscripts that, in the future, will be submitted to the histochemical journals, which will continue to be an open forum for scientists active in biomedical research, and to exert a promoting action on the development of histochemistry in its technical improvements and novel applications.

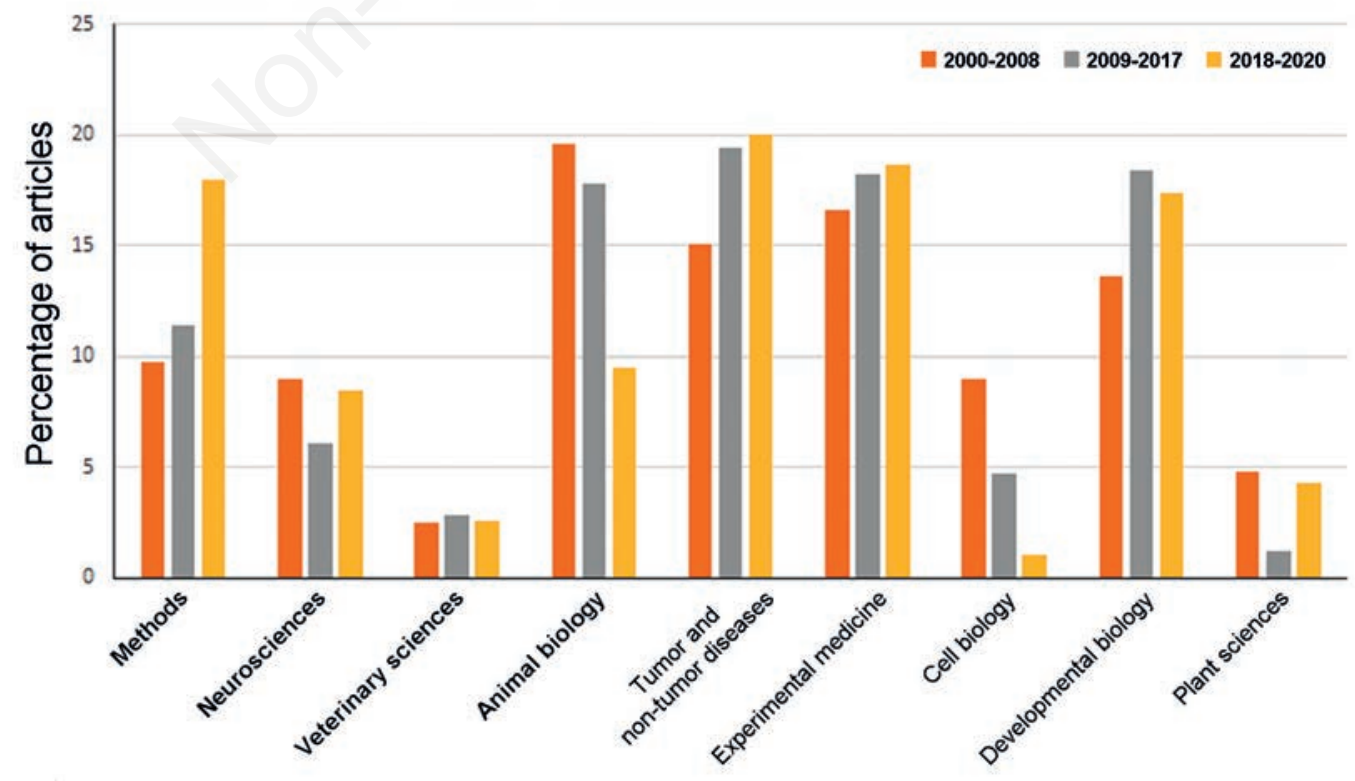

Figure 3. Number of articles published in the European Journal of Histochemistry from 2000 to 2008, 2009 to 2017 , and 2018 to present. 


\section{References}

1. Coleman R. The impact of histochemistry - A historical perspective. Acta Histochem 2000;102:5-14.

2. Coleman R. Histochemistry in the new millennium: a time to change our terminology? Acta Histochem 2000:102:241-6.

3. Pellicciari C. Histochemistry as a versatile research toolkit in biological research, not only an applied discipline in pathology. Eur J Histochem 2018;62:3006. doi: 10.4081/ejh.2018. 3006

4. Paradiso B, Simonato M, Thiene G, Lavezzi A. From fix to fit into the autoptic human brains. Eur J Histochem 2018;62:2944. doi: 10.4081/ejh.2018.2944

5. Steicke M, Yang G, Dinh TN, Dunster-Jones M, Sargisson O, Ahmady F, et al. The penetration of methanol into bovine cardiac and hepatic tissues is faster than ethanol and formalin. Eur $\mathrm{J}$ Histochem 2018;62:2880. doi: 10.4081/ejh.2018.2880

6. Röhe I, Hüttner FJ, Plendl J, Drewes B, Zentek J. Comparison of different histological protocols for the preservation and quantification of the intestinal mucus layer in pigs. Eur $\mathrm{J}$ Histochem 2018;62:2874. doi: 10.4081/ejh.2018.2874

7. Rieger J, Drewes B, Hünigen H, Plendl J. Mucosubstances in the porcine gastrointestinal tract: Fixation, staining and quantification. Eur J Histochem 2019;63:3030. doi: 10.4081/ejh.2019.3030

8. Alonzi T, Petruccioli E, Vanini V, Fimia GM, Goletti D. Optimization of the autophagy measurement in a human cell line and primary cells by flow cytometry. Eur J Histochem 2019;63:3044. doi: 10.4081/ejh.2019.3044

9. Costanzo M, Malatesta M. Embedding cell monolayers to investigate nanoparticle-plasmalemma interactions at transmission electron microscopy. Eur J Histochem 2019;63:3026. doi: 10.4081/ejh.2019.3026

10. Begam M, Roche JA. Damaged muscle fibers might masquerade as hybrid fibers - a cautionary note on immunophenotyping mouse muscle with mouse monoclonal antibodies. Eur J Histochem 2018;62:2896. doi: 10.4081/ejh.2018.2896

11. Cheng XE, Ma LX, Feng XJ, Zhu MY, Zhang DY, Xu LL, et al. Antigen retrieval pre-treatment causes a different expression pattern of Cav3.2 in rat and mouse spinal dorsal horn. Eur J Histochem 2019;63:2988. doi: 10.4081/ejh.2019.2988

12. Gusel'nikova V, Antimonova O, Fedorova E, Shavlovsky M, Krutikov A, Mikhailova E, et al. Fluorescent characterization of amyloid deposits in the kidneys of mdx mice. Eur J Histochem 2018;62:2870. doi: 10.4081/ejh.2018.2870

13. Braak H, Feldengut S, Kassubek J, Yilmazer-Hanke D, Del Tredici K. Two histological methods for recognition and study of cortical microinfarcts in thick sections. Eur J Histochem 2018;62:2989. doi: 10.4081/ejh.2018.2989

14. Pigoli C, Gibelli LR, Caniatti M, Moretti L, Sironi G, Giudice C. Bleaching melanin in formalin-fixed and paraffin-embedded melanoma specimens using visible light: a pilot study. Eur J Histochem 2019;63:3071. doi: 10.4081/ejh.2019.3071

15. Carton F, Repellin M, Lollo G, Malatesta M. Alcian blue staining to track the intracellular fate of hyaluronic-acid-based nanoparticles at transmission electron microscopy. Eur J Histochem 2019;63:3086. doi: 10.4081/ejh.2019.3086

16. Malatesta M. Ultrastructural histochemistry in biomedical research: Alive and kicking. Eur J Histochem 2018;62:2990. doi: 10.4081/ejh.2018.2990

17. Krijgsman D, Van Vlierberghe RLP, Evangelou V, Vahrmeijer AL, Van de Velde CJH, Sier CFM, et al. A method for semi-automated image analysis of HLA class I tumour epithelium expression in rectal cancer. Eur J Histochem 2019;63:3028. doi: 10.4081/ejh.2019.3028

18. Boschi F, Rizzatti V, Zoico E, Montanari T, Zamboni M, Sbarbati A, et al. Relationship between lipid droplets size and integrated optical density. Eur J Histochem 2019;63:3017. doi: 10.4081/ejh.2019.3017

19. Calderan L, Malatesta M. Imaging techniques in nanomedical research. Eur J Histochem 2020;64:3151. doi: 10.4081/ ejh.2020.3151

20. Scimeca M, Bischetti S, Lamsira HK, Bonfiglio R, Bonanno E. Energy Dispersive X-ray (EDX) microanalysis: A powerful tool in biomedical research and diagnosis. Eur $\mathrm{J}$ Histochem 2018;62:2841. doi: 10.4081/ejh.2018.2841

21. Casini A, Vaccaro R, Toni M, Cioni C. Distribution of choline acetyltransferase (ChAT) immunoreactivity in the brain of the teleost Cyprinus carpio. Eur J Histochem 2018;62:2932. doi: 10.4081/ejh.2018.2932

22. Kassa RM, Bonafede R, Boschi F, Malatesta M, Mariotti R. The role of mutated SOD1 gene in synaptic stripping and MHC class I expression following nerve axotomy in ALS murine model. Eur J Histochem 2018;62:2904. doi: 10.4081/ejh.2018.2904

23. Nishida K, Nomura Y, Kawamori K, Ohishi A, Nagasawa K. ATP metabolizing enzymes ENPP1, 2 and 3 are localized in sensory neurons of rat dorsal root ganglion. Eur J Histochem 2018;62:2877. doi: 10.4081/ejh.2018.2877

24. Ma B, Yin C, Hu D, Newman M, Nicholls PK, Wu Z, et al. Distribution of non-myelinating Schwann cells and their associations with leukocytes in mouse spleen revealed by immunofluorescence staining. Eur J Histochem 2018;62:2890. doi: 10.4081/ ejh.2018.2890

25. Farina V, Lepore G, Biagi F, Carcupino M, Zedda M. Autophagic processes increase during senescence in cultured sheep neurons and astrocytes. Eur J Histochem 2018;62:2891. doi: 10.4081/ejh.2018.2891

26. Hu D, Nicholls PK, Claus M, Wu Y, Shi Z, Greene WK, et al. Immunofluorescence characterization of innervation and nerveimmune cell interactions in mouse lymph nodes. Eur J Histochem 2019;63:3059. doi: 10.4081/ejh.2019.3059

27. Danková M, Domoráková I, Fagová Z, Stebnický M, Kunová A, Mechírová E. Bradykinin and noradrenaline preconditioning influences level of antioxidant enzymes SOD, CuZn-SOD, MnSOD and catalase in the white matter of spinal cord in rabbits after ischemia/reperfusion. Eur J Histochem 2019;63:3045. doi: 10.4081/ejh.2019.3045

28. $\mathrm{Xu} \mathrm{N}$, Li AD, Ji LL, Ye Y, Wang ZY, Tong L. miR-132 regulates the expression of synaptic proteins in APP/PS1 transgenic mice through C1q. Eur J Histochem 2019;63:3008. doi: 10.4081/ejh.2019.3008

29. Pompili E, Ciraci V, Leone S, De Franchis V, Familiari P, Matassa $\mathrm{R}$, et al. Thrombin regulates the ability of Schwann cells to support neuritogenesis and to maintain the integrity of the nodes of Ranvier. Eur J Histochem 2020;64:3109. doi: 10.4081/ejh.2020.3109

30. Dall'Aglio C, Scocco P, Maranesi M, Petrucci L, Acuti G, De Felice E, et al. Immunohistochemical identification of resistin in the uterus of ewes subjected to different diets: Preliminary results. Eur J Histochem 2019;63:3020. doi: 10.4081/ejh. 2019.3020

31. Mercati F, Dall'Aglio C, Timperi L, Scocco P, De Felice E, Maranesi M. Epithelial expression of the hormone leptin by bovine skin. Eur J Histochem 2019;63:2993. doi: 10.4081/ejh.2019.2993

32. Dall'Aglio C, Mercati F, Faeti V, Acuti G, Trabalza Marinucci M, De Felice E, et al. Immuno- and glyco-histochemistry as a tool to evaluate the oregano supplemented feed effects in pig gut. Eur J Histochem 2020;64:3110. doi: 10.4081/ejh. 2020.3110

33. Reginato GS, Barbosa GK, Ferreira AO, Vasconcelos BG, Rici REG, Watanabe IS, et al. Morphological and ultrastructural characteristics of the tongue of wild boar. Eur $\mathrm{J}$ Histochem 2020;64:3128. doi: 10.4081/ejh.2020.3128 
34. Yu W, Zhang Z, Liu P, Yang X, Zhang H, Yuan Z, et al. Seasonal expressions of SPAG11A and androgen receptor in the epididymis of the wild ground squirrels (Citellus dauricus Brandt). Eur J Histochem 2020;64:3111. doi: 10.4081/ejh.2020.3111

35. Rosati L, Prisco M, Di Lorenzo M, De Falco M, Andreuccetti P. Immunolocalization of aromatase P450 in the epididymis of Podarcis sicula and Rattus rattus. Eur J Histochem 2020;64:3080. doi: 10.4081/ejh.2020.3080

36. Basso PR, Carava' E, Protasoni M, Reguzzoni M, Raspanti M. The synovial surface of the articular cartilage. Eur J Histochem 2020;64:3146. doi: 10.4081/ejh.2020.3146

37. Dela Justina V, San Martin S, López-Espíndola D, Bressan AFM, Alves de Freitas R, Lopes de Passos AM, et al. Increased expression of STAT3 and SOCS3 in placenta from hyperglycemic rats. Eur J Histochem 2019;63:3054. doi: 10.4081/ejh.2019.3054

38. Huang W, Li W, Liu J, Hou J, Meng H. Ferritin expression in the periodontal tissues of primates. Eur J Histochem 2019;63:3046. doi: 10.4081/ejh.2019.3046

39. Ge T, Ye Y, Zhang H. Ultrastructure of telocytes, a new type of interstitial cells in the myocardium of the Chinese giant salamander (Andrias davidianus). Eur J Histochem 2019;63:3021. doi: 10.4081/ejh.2019.3021

40. Kaptaner B. Immunohistochemical distribution of insulin-, glucagon- and somatostatin-containing cells in the pancreas of Lake Van fish (Alburnus tarichi Güldenstädt, 1814) (Cyprinidae). Eur J Histochem 2019;63:2999. doi: 10.4081/ejh.2019.2999

41. Xie W, Liu H, Liu Q, Gao Q, Gao F, Han Y, et al. Seasonal expressions of prolactin, prolactin receptor and STAT5 in the scented glands of the male muskrats (Ondatra zibethicus). Eur J Histochem 2019;63(1):2991. doi: 10.4081/ejh.2019.2991.

42. Wang Y, Wang Z, Yu W, Sheng X, Zhang H, Han Y, et al. Seasonal expressions of androgen receptor, estrogen receptors and cytochrome P450 aromatase in the uteri of the wild Daurian ground squirrels (Spermophilus dauricus). Eur J Histochem 2018;62:2889. doi: 10.4081/ejh.2018.2889

43. Polakovičová S, Csöbönyeiová M, Filova B, Borovský M, Maršík L, Kvasilová A, et al. Merkel-like cell distribution in the epithelium of the human vagina. An immunohistochemical and TEM study. Eur J Histochem 2018;62:2836. doi: 10.4081/ejh.2018.2836

44. Mammola CL, Vetuschi A, Pannarale L, Sferra R, Mancinelli R. Epidermal growth factor-like domain multiple 7 (EGFL7): Expression and possible effect on biliary epithelium growth in cholangiocarcinoma. Eur J Histochem 2018;62:2971. doi: 10.4081/ejh.2018.2971

45. Rabinovich I, Sebastião APM, Lima RS, Urban CA, Junior ES, Anselmi KF, et al. Cancer stem cell markers ALDH1 and CD44+/CD24- phenotype and their prognosis impact in invasive ductal carcinoma. Eur J Histochem 2018;62:2943. doi: 10.4081/ejh.2018.2943

46. De Souza Albuquerque MS, Da Silva-Filho AF, Ferraz Cordeiro M, Deodato de Souza MF, Quirino MWL, Amorim Lima LR, et al. GalNAc-T15 in gastric adenocarcinoma: Characterization according to tissue architecture and cellular location. Eur J Histochem 2018;62:2931. doi: 10.4081/ ejh.2018.293.

47. Salucci S, Burattini S, Buontempo F, Orsini E, Furiassi L, Mari M, et al. Marine bisindole alkaloid: A potential apoptotic inducer in human cancer cells. Eur J Histochem 2018;62:2881. doi: 10.4081/ejh.2018.2881

48. Moudi B, Heidari Z, Mahmoudzadeh-Sagheb H, Alavian SM, Lankarani KB, Farrokh P, et al. Concomitant use of heat-shock protein 70 , glutamine synthetase and glypican-3 is useful in diagnosis of HBV-related hepatocellular carcinoma with higher specificity and sensitivity. Eur J Histochem 2018;62:2859. doi: 10.4081/ejh.2018.2859
49. Li X, Yang S, Zhang M, Xie S, Xie Z. Downregulation of SRPK2 promotes cell cycle arrest though E2F1 in non-small cell lung cancer. Eur J Histochem 2019;63:3067. doi: 10.4081/ejh.2019.3067

50. Corlan AS, Cîmpean AM, Melnic E, Raica M, Sarb S. VEGF, VEGF165b and EG-VEGF expression is specifically related with hormone profile in pituitary adenomas. Eur $\mathrm{J}$ Histochem 2019;63:3010. doi: 10.4081/ejh.2019.3010

51. Wolosz D, Walczak A, Szparecki G, Dwojak M, Winiarska M, Wolinska E, et al. Deleted in Liver Cancer 2 (DLC2) protein expression in hepatocellular carcinoma. Eur J Histochem 2019;63:2981. doi: 10.4081/ejh.2019.2981

52. Zhou Y, Liu S, Luo Y, Zhang M, Jiang X, Xiong Y. IncRNA MAPKAPK5-AS1 promotes proliferation and migration of thyroid cancer cell lines by targeting miR-519e-5p/YWHAH. Eur J Histochem 2020;64:3177. doi: 10.4081/ejh.2020.3177

53. Karas Zella MA, Sebastião APM, Collaço LM, Ogata DC, Cecchetti G, Bartolomei IJP, et al. Prognostic significance of CD133 and ABCB5 expression in papillary thyroid carcinoma. Eur J Histochem 2020;64:3143. doi: 10.4081/ejh. 2020.3143

54. Li H, Zeng Z, Yang X, Chen Y, He L, Wan T. LncRNA GClnc1 may contribute to the progression of ovarian cancer by regulating p53 signaling pathway. Eur J Histochem 2020;64:3166. doi: 10.4081/ejh.2020.3166

55. Mancinelli R, Cutone A, Rosa L, Lepanto MS, Onori P, Pannarale $\mathrm{L}$, et al. Different iron-handling in inflamed small and large cholangiocytes and in small and large-duct type intrahepatic cholangiocarcinoma. Eur J Histochem 2020;64):3156. doi: 10.4081/ejh.2020.3156

56. Zupančič D, Kreft ME, Sterle I, Romih R. Combined lectin- and immuno-histochemistry (CLIH) for applications in cell biology and cancer diagnosis: Analysis of human urothelial carcinomas. Eur J Histochem 2020;64:3141. doi: 10.4081/ejh.2020.3141

57. Isorna I, Esteban F, Solanellas J, Coveñas R, Muñoz M. The substance $\mathrm{P}$ and neurokinin-1 receptor system in human thyroid cancer: an immunohistochemical study. Eur $\mathrm{J}$ Histochem 2020;64:3117. doi: 10.4081/ejh.2020.3117

58. Ziaran S, Harsanyi S, Bevizova K, Varchulova Novakova Z, Trebaticky B, Bujdak P, et al. Expression of E-cadherin, Ki-67, and p53 in urinary bladder cancer in relation to progression, survival, and recurrence. Eur J Histochem 2020;64:3098. doi: 10.4081/ejh.2020.3098

59. Visonà SD, Benati $\mathrm{D}$, Monti MC, Galiè M, Andrello L, Frontini A, et al. Diagnosis of sudden cardiac death due to early myocardial ischemia: An ultrastructural and immunohistochemical study. Eur J Histochem 2018;62:2866. doi: 10.4081/ejh.2018.2866

60. Battistelli M, Favero M, Burini D, Trisolino G, Dallari D, De Franceschi L, et al. Morphological and ultrastructural analysis of normal, injured and osteoarthritic human knee menisci. Eur J Histochem 2019;63:2998. doi: 10.4081/ejh.2019.2998

61. Franchitto A, Overi D, Mancinelli R, Mitterhofer AP, Muiesan P, Tinti F, et al. Peribiliary gland damage due to liver transplantation involves peribiliary vascular plexus and vascular endothelial growth factor. Eur J Histochem 2019;63:3022. doi: 10.4081/ejh.2019.3022.

62. Licini C, Farinelli L, Cerqueni G, Hosein A, Marchi S, Gigante A, et al. Heterotopic ossification in a patient with diffuse idiopathic skeletal hyperostosis: Input from histological findings. Eur $\mathrm{J}$ Histochem 2020;64:3176. doi: 10.4081/ejh.2020.3176

63. Li Z, Hong Z, Zheng Y, Dong Y, He W, Yuan Y, et al. An emerging potential therapeutic target for osteoporosis: LncRNA H19/miR29a-3p axis. Eur J Histochem 2020;64:3155. doi: 10.4081/ejh.2020.3155

64. Li P, Zheng J, Bai Y, Wang D, Cui Z, Li Y, et al. Characterization of kynurenine pathway in patients with diarrhea-predominant irritable bowel syndrome. Eur J Histochem 2020;64:3132. doi: 
10.4081/ejh.2020.3132

65. Loreto C, Caltabiano R, Graziano ACE, Castorina S, Lombardo $\mathrm{C}$, Filetti $\mathrm{V}$, et al. Defense and protection mechanisms in lung exposed to asbestiform fiber: the role of macrophage migration inhibitory factor and heme oxygenase-1. Eur J Histochem 2020;64:3073. doi: 10.4081/ejh. 2020.3073

66. Inomata T, Miwa Y, Kawata S, Omotehara T, Sato I, Itoh M. Immunohistochemical study for relationship between vessel and lymphatic properties and tooth marks in human oral mucosa. Eur J Histochem 2020;64:3095. doi: 10.4081/ejh. 2020.3095

67. Široká M, Franco C, Gul'ašová Z, Hertelyová Z, Tomečková V, Rodella LF, et al. Nuclear factor-kB and nitric oxide synthases in red blood cells: good or bad in obesity? A preliminary study. Eur J Histochem 2020;64:3081. doi: 10.4081/ejh. 2020.3081

68. Vetuschi A, Pompili S, Di Marco GP, Calvaruso F, Iacomino E, Angelosante L, et al. Can the AGE/RAGE/ERK signalling pathway and the epithelial-to-mesenchymal transition interact in the pathogenesis of chronic rhinosinusitis with nasal polyps? Eur J Histochem 2020;64:3079. doi: 10.4081/ejh. 2020.3079

69. Loreto C, Filetti V, Almeida LE, La Rosa GRM, Leonardi R, Grippaudo C, et al. MMP-7 and MMP-9 are overexpressed in the synovial tissue from severe temporomandibular joint dysfunction. Eur J Histochem 2020;64:3113. doi: 10.4081/ejh. 2020.3113

70. Mangas A, Heredia M, Riolobos A, De la Fuente A, Criado JM, Yajeya J, et al. Overexpression of kynurenic acid and 3-hydroxyanthranilic acid after rat traumatic brain injury. Eur J Histochem 2018;62:2985. doi: 10.4081/ejh.2018.2985

71. Sferra R, Pompili S, Ventura L, Dubuquoy C, Speca S, Gaudio E, et al. Interaction between sphingosine kinase/sphingosine 1 phosphate and transforming growth factor- $\beta /$ Smads pathways in experimental intestinal fibrosis. An in vivo immunohistochemical study. Eur J Histochem 2018;62:2956. doi: 10.4081/ ejh.2018.2956

72. Smerdu V, Perše M. Effect of high-fat mixed lipid diet and swimming on fibre types in skeletal muscles of rats with colon tumours. Eur J Histochem 2018;62:2945. doi: 10.4081/ejh.2018.2945

73. Bobek G, Stait-Gardner T, Price W, Makris A, Hennessy A. Quantification of placental change in mouse models of preeclampsia using magnetic resonance microscopy. Eur J Histochem 2018;62:2868. doi: 10.4081/ejh.2018.2868

74. Yamagishi K, Tsukamoto I, Nakamura F, Hashimoto K, Ohtani K, Akagi M. Activation of the renin-angiotensin system in mice aggravates mechanical loading-induced knee osteoarthritis. Eur J Histochem 2018;62:2930. doi: 10.4081/ejh.2018.2930

75. Hashimoto K, Oda Y, Nakagawa K, Ikeda T, Ohtani K, Akagi M. LOX-1 deficient mice show resistance to zymosan-induced arthritis. Eur J Histochem 2018;62:2847. doi: 10.4081/ejh.2018.2847

76. Amaroli A, Ferrando S, Pozzolini M, Gallus L, Parker S, Benedicenti S. The earthworm Dendrobaena veneta (Annelida): A new experimental-organism for photobiomodulation and wound healing. Eur J Histochem 2018;62:2867. doi: 10.4081/ejh.2018.2867

77. Jacob CDS, Rocha LC, Neto JP, Watanabe IS, Ciena AP. Effects of physical training on sarcomere lengths and muscle-tendon interface of the cervical region in an experimental model of menopause. Eur J Histochem 2019;63:3038. doi: 10.4081/ejh.2019.3038

78. Gao Z, Song GY, Ren LP, Ma HJ, Ma BQ, Chen SC. $\beta$-catenin mediates the effect of GLP-1 receptor agonist on ameliorating hepatic steatosis induced by high fructose diet. Eur J Histochem 2020;64:3160. doi: 10.4081/ejh.2020.3160

79. Zhang Z, Long C, Guan Y, Song M. Hepatocyte growth factor intervention to reduce myocardial injury and improve cardiac function on diabetic myocardial infarction rats. Eur J Histochem 2020;64:3142. doi: 10.4081/ejh.2020.3142
80. Uyttebroek L, Pype C, Hubens G, Timmermans JP, Van Nassauw L. Effect of TNBS-induced colitis on enteric neuronal subpopulations in adult zebrafish. Eur J Histochem 2020;64:3161. doi: 10.4081/ejh.2020.3161

81. Ghiselli R, Lucarini G, Ortenzi M, Salvolini E, Saccomanno S, Orlando F, et al. Anastomotic healing in a rat model of peritonitis after non-steroidal anti-inflammatory drug administration. Eur J Histochem 2020;64:3085. doi: 10.4081/ejh. 2020.3085

82. Colitti M, Boschi F, Montanari T. Dynamic of lipid droplets and gene expression in response to $\beta$-aminoisobutyric acid treatment on 3T3-L1 cells. Eur J Histochem 2018;62:2984. doi: 10.4081/ejh.2018.2984

83. Berardo C, Siciliano V, Di Pasqua LG, Richelmi P, Vairetti M, Ferrigno A. Comparison between Lipofectamine RNAiMAX and GenMute transfection agents in two cellular models of human hepatoma. Eur J Histochem 2019;63:3048. doi: 10.4081/ejh.2019.3048

84. Ferrigno A, Berardo C, Di Pasqua LG, Cagna M, Siciliano V, Richelmi P, et al. The selective blockade of metabotropic glutamate receptor-5 attenuates fat accumulation in an in vitro model of benign steatosis. Eur J Histochem 2020;64:3175. doi: 10.4081/ejh.2020.3175

85. Xiao S, Tang H, Bai Y, Zou R, Ren Z, Wu X, et al. Swertiamarin suppresses proliferation, migration, and invasion of hepatocellular carcinoma cells via negative regulation of FRAT1. Eur J Histochem 2020;64:3169. doi: 10.4081/ejh. 2020.3169

86. Ouyang J, Song F, Li H, Yang R, Huang H. miR-126 targeting GOLPH3 inhibits the epithelial-mesenchymal transition of gastric cancer BGC-823 cells and reduces cell invasion. Eur J Histochem 2020;64:3168. doi: 10.4081/ejh.2020.3168

87. Fu HR, Li XS, Zhang YH, Feng BB, Pan LH. Visnagin ameliorates myocardial ischemia/reperfusion injury through the promotion of autophagy and the inhibition of apoptosis. Eur J Histochem 2020;64:3131. doi: 10.4081/ejh.2020.3131

88. Donetti E, Lombardo G, Indino S, Cornaghi L, Arnaboldi F, Pescitelli L, et al. The psoriatic shift induced by interleukin 17 is promptly reverted by a specific anti-IL-17A agent in a threedimensional organotypic model of normal human skin culture. Eur J Histochem 2020;64:3115. doi: 10.4081/ejh.2020.3115

89. Costanzo M, Romeo A, Cisterna B, Calderan L, Bernardi P, Covi $\mathrm{V}$, et al. Ozone at low concentrations does not affect motility and proliferation of cancer cells in vitro. Eur J Histochem 2020;64:3119. doi: 10.4081/ejh.2020.3119

90. Mitsuoka K, Miwa Y, Kikutani T, Sato I. Localization of CGRP and VEGF mRNAs in the mouse superior cervical ganglion during pre- and postnatal development. Eur J Histochem 2018;62:2976. doi: 10.4081/ejh.2018.2976

91. Longo M, Boiani M, Redi C, Monti M. Cytoplasmic lattices are not linked to mouse 2-cell embryos developmental arrest. Eur J Histochem 2018;62:2972. doi: 10.4081/ejh.2018.2972

92. Liu W, Wang C, Yu H, Liu S, Yang J. Expression of acetylated tubulin in the postnatal developing mouse cochlea. Eur J Histochem 2018;62:2942. doi: 10.4081/ejh.2018.2942

93. Martins MF, Martins P, Gonçalves CA. Presence of N-acetylgalactosamine/galactose residues on bronchioloalveolar cells during rat postnatal development. Eur J Histochem 2019;63:3040. doi: 10.4081/ejh.2019.3040

94. Hou S, Chen J, Yang J. Autophagy precedes apoptosis during degeneration of the Kölliker's organ in the development of rat cochlea. Eur J Histochem 2019;63:3025. doi: 10.4081/ejh. 2019.3025

95. Martins MF, Freitas MS, Honório-Ferreira A, Gonçalves CA. Presence of $\mathrm{N}$-acetylneuraminic acid in the lung during postnatal development. Eur J Histochem 2020;64:3124. doi: 10.4081/ejh. 2020.3124 
96. Randilini A, Fujikawa K, Shibata S. Expression, localization and synthesis of small leucine-rich proteoglycans in developing mouse molar tooth germ. Eur J Histochem 2020;64:3092. doi: 10.4081/ejh.2020.3092

97. Manca R, Glomski CA, Pica A. Evolutionary intraembryonic origin of vertebrate hematopoietic stem cells in the elasmobranch spleen. Eur J Histochem 2018;62:2987. doi: 10.4081/ejh. 2018.2987

98. Costanzo M, Boschi F, Carton F, Conti G, Covi V, Tabaracci G, et al. Low ozone concentrations promote adipogenesis in human adipose-derived adult stem cells. Eur J Histochem 2018;62:2969. doi: 10.4081/ejh.2018.2969

99. Manca R, Glomski C, Pica A. Hematopoietic stem cells debut in embryonic lymphomyeloid tissues of elasmobranchs. Eur J Histochem 2019;63:3060. doi: 10.4081/ejh.2019.3060

100. Faraj R, Irizarry-Alfonzo A, Puri P. Molecular characterization of nephron progenitors and their early epithelial derivative structures in the nephrogenic zone of the canine fetal kidney. Eur J Histochem 2019;63:3049. doi: 10.4081/ejh.2019.3049

101. Rebuzzini P, Civello C, Nantia Akono E, Fassina L, Zuccotti M, Garagna S. Chronic cypermethrin exposure alters mouse embryonic stem cell growth kinetics, induces Phase II detoxification response and affects pluripotency and differentiation gene expression. Eur J Histochem 2020;64:3084. doi: 10.4081/ejh.2020.3084

102. Conti G, Bertossi D, Dai Prè E, Cavallini C, Scupoli MT, Ricciardi G, et al. Regenerative potential of the Bichat fat pad determined by the quantification of multilineage differentiating stress enduring cells. Eur J Histochem 2018;62:2900. doi: 10.4081/ejh.2018.2900

103. Kawai M, Kataoka Y, Sonobe J, Yamamoto H, Maruyama H, Yamamoto T, et al. Analysis of mineral apposition rates during alveolar bone regeneration over three weeks following transfer of BMP-2/7 gene via in vivo electroporation. Eur J Histochem 2018;62:2947. doi: 10.4081/ejh.2018.2947

104. Boháč M, Danišovič L, Koller J, Dragúňová J, Varga I. What happens to an acellular dermal matrix after implantation in the human body? A histological and electron microscopic study. Eur J Histochem 2018;62:2873. doi: 10.4081/ejh.2018.2873
105. Pizzicannella J, Marconi GD, Pierdomenico SD, Cavalcanti MFXB, Diomede F, Trubiani O. Bovine pericardium membrane, gingival stem cells, and ascorbic acid: a novel team in regenerative medicine. Eur J Histochem 2019;63:3064. doi: 10.4081/ejh.2019.3064

106. Wu L, Han D, Jiang J, Xie X, Zhao X, Ke T, et al. Co-transplantation of bone marrow mesenchymal stem cells and monocytes in the brain stem to repair the facial nerve axotomy. Eur J Histochem 2020;64:3136. doi: 10.4081/ejh.2020.3136

107. Antonini E, Zara C, Valentini L, Gobbi P, Ninfali P, Menotta M. Novel insights into pericarp, protein body globoids of aleurone layer, starchy granules of three cereals gained using atomic force microscopy and environmental scanning electronic microscopy. Eur J Histochem 2018;62:2869. doi: 10.4081/ejh.2018.2869

108. Lanza B, Panato A, Valentini L, Rodegher P, Bortolotti F, Battistelli M, et al. A morphological analysis of fresh and brinecured olives attacked by Bactrocera oleae using light microscopy and ESEM-EDS. Eur J Histochem 2020;64:3149. doi: 10.4081/ejh.2020.3149.

109. Falsini S, Tani C, Schiff S, Gonnelli C, Clemente I, Ristori S, Papini A. A new method for the direct tracking of in vivo lignin nanocapsules in Eragrostis tef (Poaceae) tissues. Eur J Histochem 2020;64:3112. doi: 10.4081/ejh.2020.3112

110. Ninfali P, Panato A, Bortolotti F, Valentini L, Gobbi P. Morphological analysis of the seeds of three pseudocereals by using light microscopy and ESEM-EDS. Eur J Histochem 2020;64:3075. doi: 10.4081/ejh.2020.307.

111. Raspail FV. Essai de chimie microscopique appliquée à la physiologie, ou l'art de transporter le laboratoire sur le porte-objet dans l'étude des corps organisés. Ann Science d'Observations II 1829:430-45.

112. Baddeley D, Bewersdorf J. Biological insight from super-resolution microscopy: What we can learn from localization-based images. Annu Rev Biochem 2018;87:965-89.

113. Mao C, Lee MY, Jhan J-R, Halpern AR, Woodworth MA, Glaser $\mathrm{AK}$, et al. Feature-rich covalent stains for super-resolution and cleared tissue fluorescence microscopy. Sci Adv 2020;6: eaba4542. doi: 10.1126/sciadv.aba4542

Received for publication: 28 December 2020. Accepted for publication: 28 December 2020

This work is licensed under a Creative Commons Attribution-NonCommercial 4.0 International License (CC BY-NC 4.0).

(C) Copyright: the Author(s), 2020

Licensee PAGEPress, Italy

European Journal of Histochemistry 2020; 64:3213

doi:10.4081/ejh.2020.3213 